\title{
Cryptosporidium Removal from Runoff by Active Carbon Filter with Coal Gangue
}

\author{
Ping Lu, ${ }^{1}$ Tao Yuan, ${ }^{1,2,3}$ and Baojun Zhang ${ }^{2,3}$ \\ ${ }^{1}$ Department of Environmental Science and Spatial Informatics, China University of Mining and Technology, Xuzhou 221116, China \\ ${ }^{2}$ Department of Construction Equipment and Municipal Engineering, Jiangsu Vocational Institute of Architectural Technology, \\ Xuzhou, Jiangsu 221000, China \\ ${ }^{3}$ Jiangsu Collaborative Innovation Center for Building Energy Saving and Construct Technology, Xuzhou 221116, China
}

Correspondence should be addressed to Ping Lu; lupingcumt@126.com

Received 16 November 2015; Accepted 12 June 2016

Academic Editor: Yuangen Yang

Copyright (C) 2016 Ping Lu et al. This is an open access article distributed under the Creative Commons Attribution License, which permits unrestricted use, distribution, and reproduction in any medium, provided the original work is properly cited.

\begin{abstract}
Transport of Cryptosporidium in runoff will contaminate the surrounding water body. Cryptosporidium-sized microspheres and inactive Cryptosporidium parvum oocysts removal using an active carbon (AC) filter with/without coal gangue from the runoff was evaluated. Chemical composition of coal gangue was determined, and its performance as a water treatment material was tested. Results showed $\mathrm{SiO}_{2}$ was the dominant chemical component of coal gangue. Removal was only $20 \%$ for microspheres and $24 \%$ for oocysts by AC filtration alone. The removal for both was increased to more than $98 \%$ by addition of coal gangue powder to the filter. Furthermore, gangue reuse turned commercially worthless material to a water treatment material as well helping prevent gangue from occupying agriculture/industry land.
\end{abstract}

\section{Introduction}

Coal gangue makes up $10 \%$ to $25 \%$ of the amount of coal yield in China, which turns to industrial wastes congregating like huge mountains in coal mining areas. In mining, gangue is the commercially worthless material and thus distinct from overburden, the waste rock or materials overlying an ore or mineral body that are displaced during mining without being processed. More than 1,600 coal gangue mountains with approximate 45 million tons of gangue are found in China. The number of gangue mountains is still increasing with the accumulation of 1.5 to 2 million tons/year. Gangue reuse rather than dumping as tailing will help to manage the waste in coal mining area and may later find a commercial use. So far, there is no reuse research on coal gangue as a water treatment material to remove Cryptosporidium from water.

Cryptosporidium is one-celled intestinal parasite with diameter of 4-6 $\mu \mathrm{m}$ and has been reported for contamination of water worldwide [1-3]. Transmission of Cryptosporidium via runoff to surface water is relatively common. However, there is limited research on Cryptosporidium removals from runoff so far.

AC filters are effective for removal of multiple contaminants from water body $[4,5]$. They are easy to install and less maintenance is required. The runoff in research area contains multiple pollutants, such as protozoan pathogen Cryptosporidium and polycyclic aromatic hydrocarbons. Here, AC filter was selected due to its large specific surface area with high adsorption. However, Cryptosporidium removals by AC filter were low indicated by the preliminary experiments. In this paper Cryptosporidium-sized microsphere and inactive Cryptosporidium parvum oocyst removals from runoff were evaluated by $\mathrm{AC}$ filter with/without coal gangue powder, intending to enhance the $\mathrm{AC}$ filter performance.

\section{Methods and Materials}

2.1. Experimental Methods. Figure 1 shows the lab-scale AC filter and runoff treatment system. AC filter height was $0.5 \mathrm{~m}$ and diameter was $0.5 \mathrm{~m}$. The filtration rate was $20 \mathrm{~m} / \mathrm{h}$. 
TABLE 1: Chemical composition (percentage) for coal gangue.

\begin{tabular}{lccccccc}
\hline Composition & $\mathrm{SiO}_{2}$ & $\mathrm{Al}_{2} \mathrm{O}_{3}$ & $\mathrm{Fe}_{2} \mathrm{O}_{3}$ & $\mathrm{CaO}$ & $\mathrm{MgO}$ & $\mathrm{Na}_{2} \mathrm{O}$ & $\mathrm{C}$ \\
\hline Content & $30 \%-60 \%$ & $20 \%-30 \%$ & $2 \%-10 \%$ & $1 \%-4 \%$ & $1 \%-2 \%$ & $1 \%-2 \%$ & $20 \%-30 \%$ \\
\hline
\end{tabular}

TABLE 2: Heavy metals in coal gangue and soil (mg/kg).

\begin{tabular}{lcccccc}
\hline & $\mathrm{Cd}$ & $\mathrm{Pb}$ & $\mathrm{Hg}$ & $\mathrm{Cr}^{6+}$ & $\mathrm{As}$ & $\mathrm{Cu}$ \\
\hline Gangue & $0.1 \pm 0.02$ & $25.2 \pm 0.25$ & $0.1 \pm 0.02$ & $53.1 \pm 0.12$ & $8.2 \pm 0.17$ & $23.8 \pm 0.1$ \\
Soil & $0.1 \pm 0.02$ & $14.7 \pm 0.35$ & $0.1 \pm 0.03$ & $52.5 \pm 0.87$ & $16.9 \pm 0.15$ & $18.2 \pm 0.25$ \\
\hline
\end{tabular}
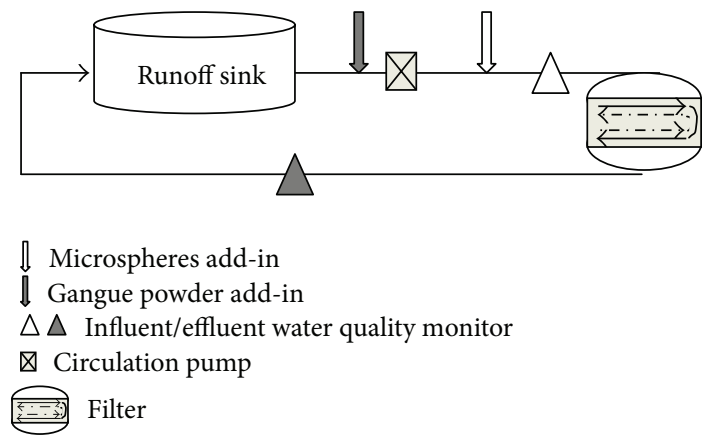

FIGURE 1: Experimental setup (100 g gangue powder was added).

The filter was backwashed every $24 \mathrm{hrs}$. Online data could be recorded and downloaded from a computer. A control experiment without gangue powder was conducted. Duplicate experiments were conducted and triplicate samples were collected.

Gangue and soil samples were collected from a local coal mining area. It was crushed into small grain $(10-30 \mathrm{~mm})$ and then ground into powder $(5 \mu \mathrm{m})$ by a grinding machine (LHE-1000, Zhengyuan Company, Shandong, China). The gangue powder was stored in dry basket for use. Chemical composition was tested by X-ray Fluorescence (XRF, EDX8800E, 3V Instrument Co,. Ltd, Suzhou, China). The gangue powder solution (volume ratio of powder/water = $1: 2$ ) was fed previous to experiment by circulation pump.

The use of polystyrene microspheres as an oocyst surrogate has been done by multiple researchers, and it was used in this study [6-13]. Microspheres with diameter of $4.5 \mu \mathrm{m}$ were used as the surrogate (Fluorsebrite ${ }^{\mathrm{TM}}$ Carboxylate YG 4.5micron microspheres, Cat. \#16592, Polysciences, Inc., Warrington, Pennsylvania, USA). Heat-inactivated C. parvum oocysts were used. Oocysts were heat-inactivated at $55^{\circ} \mathrm{C}$ for one hour prior to seeding. The concentration for both stocks was $4 \times 10^{11} \# / \mathrm{L}$. Samples were passed through $2.5 \mu \mathrm{m}$ pore size filters. Each polycarbonate filter was mounted on a glass microscope slide under an epifluorescent microscope at 100x magnification. C. parvum samples were concentrated by centrifugation twice at $4,000 \times \mathrm{g}$ at $4^{\circ} \mathrm{C}$ for 15 minutes followed by two microcentrifugation steps at $15,000 \times \mathrm{g}$ at $4^{\circ} \mathrm{C}$ for 5 minutes and detected under 200x magnification [14].

Approximately $10^{7}(1.82 \# / \mathrm{mL})$ microspheres and oocysts were fed. Filter influent and effluent samples were taken for removal calculation. Runoff combined with microspheres

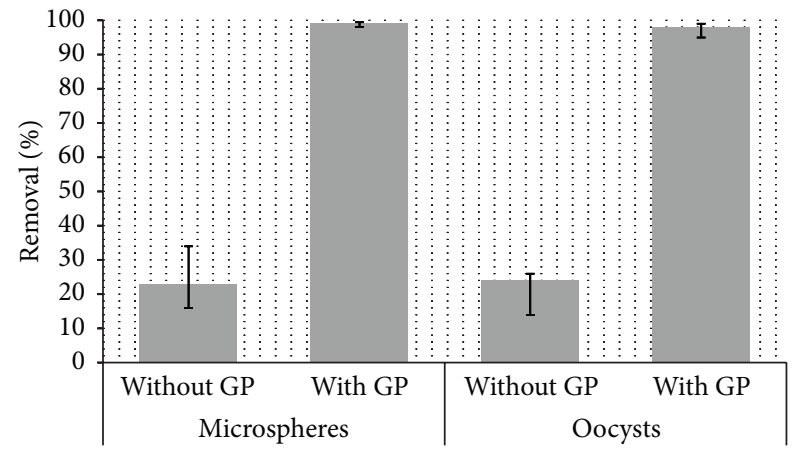

Figure 2: Cryptosporidium-sized microspheres $(1.8 \# / \mathrm{mL})$ and Cryptosporidium oocysts $(1.8 \# / \mathrm{mL})$ removal by active carbon cartridge filter with and without gangue powder (GP).

and oocysts were fed. Duplicate experiments were conducted. Triplicate samples were taken for each.

\section{Results and Discussion}

Collected gangue chemical composition is shown in Table 1. Varieties of mineral substances were found in coal gangue, which contains $\mathrm{SiO}_{2}, \mathrm{Al}_{2} \mathrm{O}_{3}, \mathrm{Fe}_{2} \mathrm{O}_{3}, \mathrm{CaO}, \mathrm{MgO}, \mathrm{Na}_{2} \mathrm{O}, \mathrm{K}_{2} \mathrm{O}$, $\mathrm{SO}_{3}, \mathrm{P}_{2} \mathrm{O}_{5}, \mathrm{C}, \mathrm{N}, \mathrm{H}$, and so forth. The max-composition was $\mathrm{SiO}_{2}$ which took up $30 \%$ to $60 \%$, while $\mathrm{Al}_{2} \mathrm{O}_{3}(20 \%$ to $30 \%$ ) took the second place, followed by $\mathrm{C}, \mathrm{MgO}$, and $\mathrm{Na}_{2} \mathrm{O}$. In addition, heavy metal concentration in coal gangue and soil was compared and shown in Table 2. Cadmium, lead, mercury, chromium, arsenic, and copper were found in coal gangue. Similar heavy metal concentration was observed between gangue and soil. The metal concentration in coal gangue and soil was below the Chinese Environmental Protection Agency limits (GB15618-1995).

Figure 2 shows the microspheres and oocysts removal with and without gangue powder addition on the surface of the AC filter. Average removals were 23\% (varied from 16\% to $34 \%$, standard deviation $=0.07$ ) and $24 \%$ (varied from $14 \%$ to $26 \%$, standard deviation $=0.05$ ) for microspheres and oocysts by AC filter, respectively. The average microsphere and oocysts removals were $99 \%$ (varied from $97 \%$ to $99.9 \%$, standard deviation $=0.01$ ) and $98 \%$ (varied from $95 \%$ to $99 \%$, standard deviation $=0.02$ ) by AC filter with gangue powder on its surface (duplicate experiments and triplicate samples). Removals of microspheres and oocysts were similar demonstrating that the microsphere was an adaptable 
Cryptosporidium surrogate. There is rare research on Cryptosporidium removal from runoff. The removal as high as $99 \%$ can be comparable with the removals of Cryptosporidium by sand filter with coagulation [15]. However, the mechanism was different from coagulation followed by sand filtration. The potential reason of gangue powder enhanced AC filter performance is similar to membrane filtration.

\section{Conclusions}

AC filter could remove 23\% of Cryptosporidium-sized microspheres and $24 \%$ of oocysts. The AC filter with gangue powder achieved $99 \%$ microspheres and $98 \%$ oocysts removal. The results indicated AC filter with coal gangue power could remove microspheres or oocysts from runoff efficiently. Using coal gangue to treat runoff was an effective way to reuse coal mining waste material as well as to deal with the gangue accumulation and stealing agriculture land issue.

\section{Competing Interests}

The authors declare that they have no competing interests.

\section{Acknowledgments}

The authors wish to thank the National Natural Science Foundation of China (41403090), the Foundation of Jiangsu Collaborative Innovation Center for Building Energy Saving and Construct Technology (SJXTY1507), and "the Fundamental Research Funds for the Central Universities" (2013QNB08).

\section{References}

[1] J. R. Harris and F. Petry, "Cryptosporidium parvum: structural components of the oocyst wall," The Journal of Parasitology, vol. 85, no. 5, pp. 839-849, 1999.

[2] L. Putignani and D. Menichella, "Global distribution, public health and clinical impact of the protozoan pathogen Cryptosporidium," Interdisciplinary Perspectives on Infectious Diseases, vol. 2010, Article ID 753512, 39 pages, 2010.

[3] P. Lu, T. Yuan, Q. Feng, A. Xu, and J. Li, "Review of swimmingassociated Cryptosporidiosis and Cryptosporidium oocysts removals from swimming pools," Water Quality Research Journal of Canada, vol. 48, no. 1, pp. 30-39, 2013.

[4] D. Vial and G. Doussau, "The use of microfiltration membranes for seawater pre-treatment prior to reverse osmosis membranes," Desalination, vol. 153, no. 1-3, pp. 141-147, 2003.

[5] Y. Wang, F. Hammes, and T. Egli, “The impact of industrialscale cartridge filtration on the native microbial communities from groundwater," Water Research, vol. 42, no. 16, pp. 43194326, 2008.

[6] J. E. Amburgey, Improving filtration for removal of Cryptosporidium Oocysts and particles from drinking water [Ph.D. thesis], Georgia Institute of Technology, Atlanta, Ga, USA, 2002.

[7] J. E. Amburgey, A. Amirtharajah, B. M. Brouckaert, and N. C. Spivey, "Effect of washwater chemistry and delayed start on filter ripening," Journal of American Water Works Association, vol. 96, no. 1, pp. 9-110, 2004.
[8] J. E. Amburgey, A. Amirtharajah, M. T. York, B. M. Brouckaert, N. C. Spivey, and M. J. Arrowood, "Comparison of conventional and biological filter performance for Cryptosporidium and microsphere removal," Journal of American Water Work Associaiton, vol. 97, no. 12, pp. 10-91, 2005.

[9] T. J. Brown and M. B. Emelko, "Chitosan and metal salt coagulant impacts on Cryptosporidium and microsphere removal by filtration," Water Research, vol. 43, no. 2, pp. 331-338, 2009.

[10] X. Dai and R. M. Hozalski, "Evaluation of microspheres as surrogates for Cryptosporidium parvum oocysts in filtration experiments," Environmental Science and Technology, vol. 37, no. 5, pp. 1037-1042, 2003.

[11] M. B. Emelko and P. M. Huck, "Microspheres as surrogates for Cryptosporidium filtration," Journal of American Water Works Association, vol. 96, no. 3, pp. 12-105, 2004.

[12] M. B. Emelko, P. M. Huck, and B. M. Coffey, "Cryptosporidium removal by filtration: a review," Journal of American Water Work Associaiton, vol. 97, no. 12, pp. 101-115, 2005.

[13] S. Y. Li, J. A. Goodrich, J. H. Owens, G. E. Willeke, F. W. I. Schaefer, and R. M. Clark, "Reliability of surrogates for determining Cryptosporidium removal," Journal of American Water Works Association, vol. 89, no. 5, pp. 90-99, 1997.

[14] P. Lu, Enhanced removal of Cryptosporidium parvum oocysts and Cryptosporidium-sized microspheres from recreational water through filtration [Ph.D. thesis], University of North Carolina at Charlotte, Charlotte, NC, USA, 2012.

[15] P. Lu and J. E. Amburgey, "A pilot-scale study of Cryptosporidium-sized microsphere removals from swimming pools via sand filtration," Journal of Water and Health, vol. 14, no. 1, pp. 109-120, 2016. 

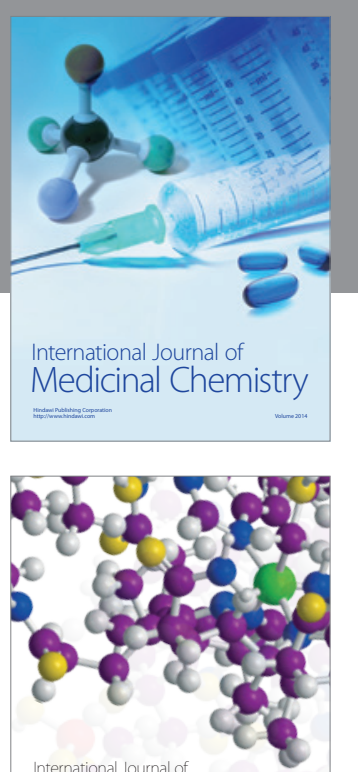

Carbohydrate Chemistry

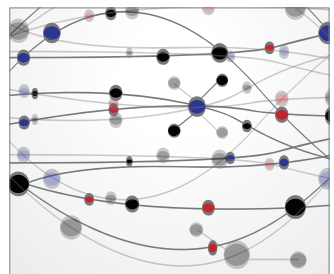

The Scientific World Journal
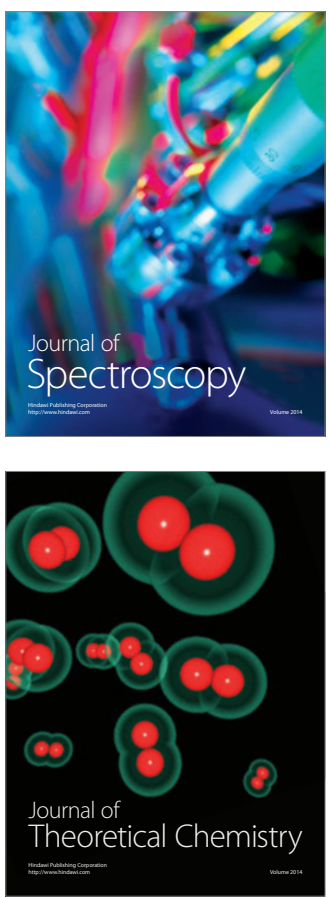
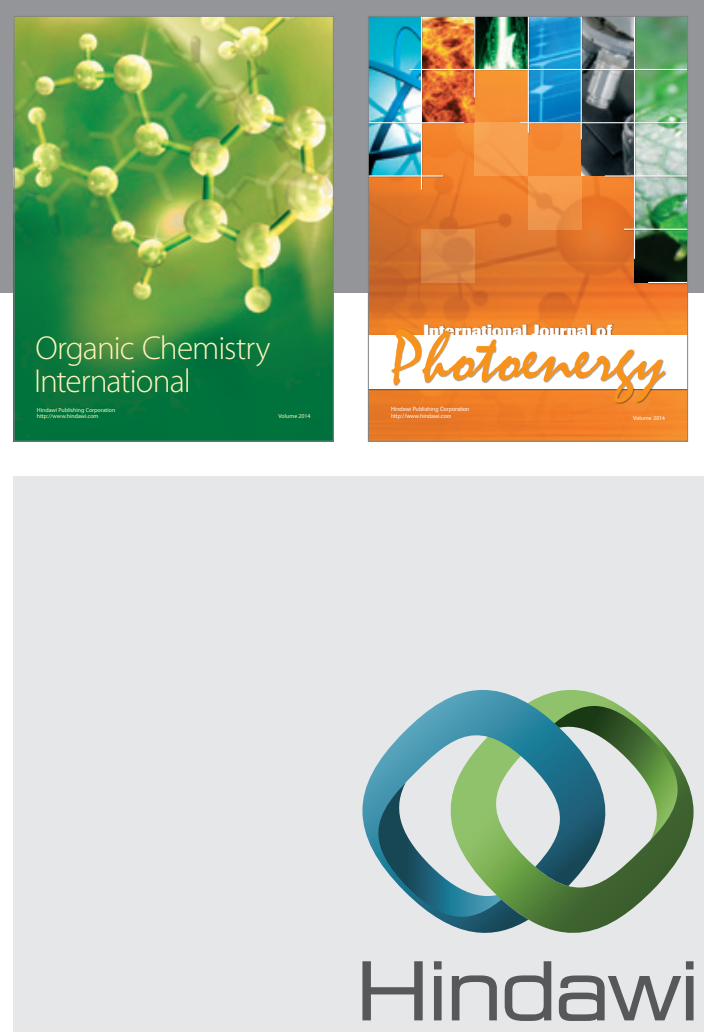

Submit your manuscripts at

http://www.hindawi.com

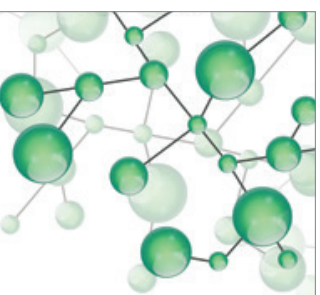

International Journal of

Inorganic Chemistry

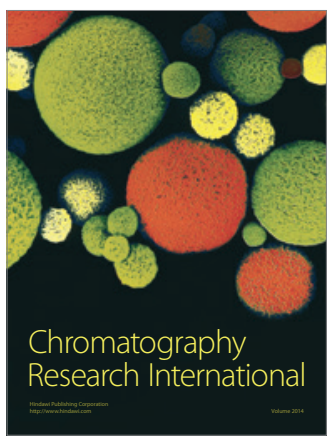

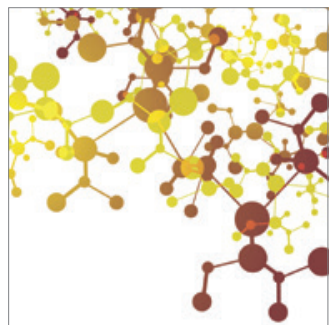

Applied Chemistry
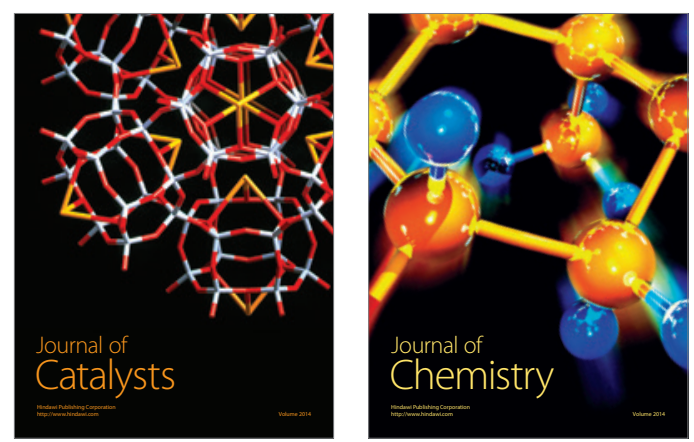
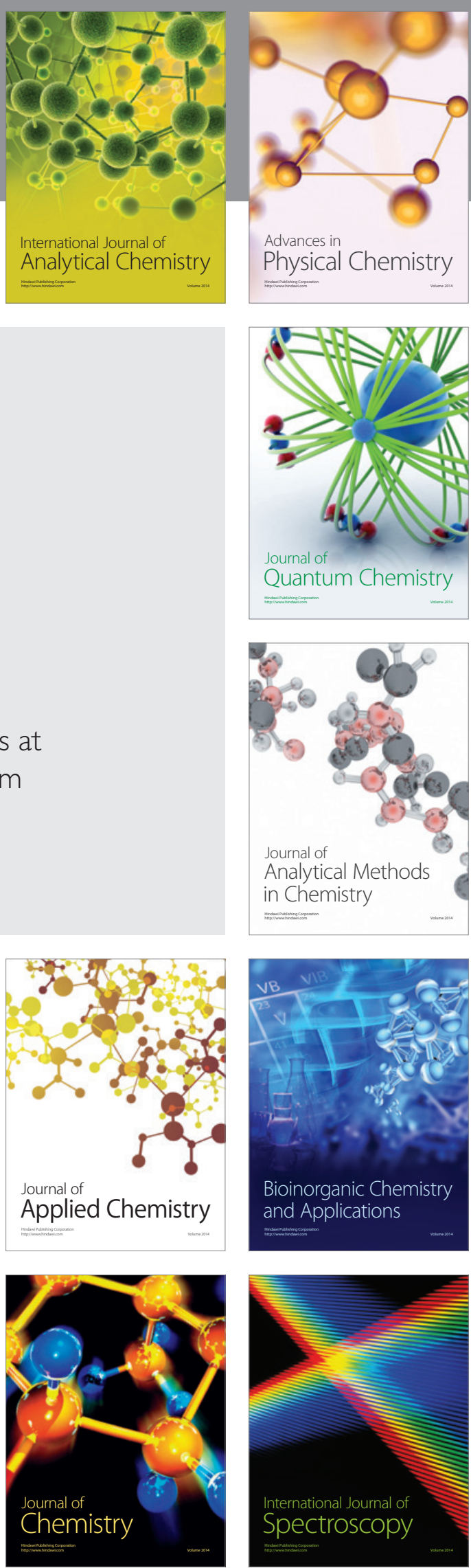